\title{
Uji efek antibakteri daun mangrove Rhizophora apiculata terhadap bakteri Pseudomonas aeruginosa dan Staphylococcus aureus
}

\author{
${ }^{1}$ Vivi P. Santoso \\ ${ }^{2}$ Jimmy Posangi \\ ${ }^{2}$ Henoch Awaloei \\ ${ }^{2}$ Robert Bara
}

\author{
${ }^{1}$ Kandidat Skripsi Bagian Farmakologi dan Terapi Kedokteran \\ Universitas Sam Ratulangi Manado \\ ${ }^{2}$ Bagian Farmakologi dan Terapi Fakultas Kedokteran Universitas Sam Ratulangi Manado \\ Email: v.santoso11_113@yahoo.com
}

\begin{abstract}
Endophytic Fungi are microorganisms that live in the plant tissue systems such as seeds, leaves, flowers, twigs, stems, and roots. Endophytic fungi used in this study was isolated from Mangrove Rhizophora apiculata leaves. $R$. apiculata is widely grown in coastal areas. This study aimed to determine whether there was an antibacterial effect of endophytic fungi that was isolated from leaves of Rhizophora apiculata against the sample bacteria Pseudomonas aeruginosa and Staphylococcus aureus. This study was conducted in the Pharmacology and Therapeutics Laboratory of Sam Ratulangi University by using experimental methods. The results showed two types of fungi, tusky white endophytic fungi and white filamentous endophytic fungi, isolated from Mangrove Rhizophora apiculata leaves. Both types of fungi showed the presence of bacterial growth inhibition, but the white filamentous endophytic fungi had greater antibacterial effect than the tusky white endophytic fungi.
\end{abstract}

Keywords: endophytic fungi, antibacterial, rhizophora apiculata leaves

\begin{abstract}
Abstrak: Jamur endofit merupakan mikroorganisme yang hidup di dalam sistem jaringan tumbuhan seperti biji, daun, bunga, ranting, batang, dan akar. Jamur endofit yang digunakan pada penelitian ini merupakan hasil isolasi dari daun mangrove Rhizophora apiculata. Tanaman mangrove R.apiculata ini banyak tumbuh di kawasan pesisir pantai. Penelitian ini bertujuan untuk mengetahui apakah terdapat efek antibakteri jamur endofit yang diisolasi dari daun Rhizophora apiculata terhadap bakteri uji Pseudomonas aeruginosa dan Staphylococcus aureus. Penelitian ini dilakukan di Laboratorium Farmakologi dan Terapi Universitas Sam Ratulangi Manado dengan menggunakan metode eksperimental. Hasil penelitian ini didapatkan dua jenis jamur yaitu jamur endofit berwarna putih gading dan jamur endofit berwarna putih berserabut yang diisolasi dari daun mangrove Rhizophora apiculata. Kedua jenis jamur menunjukan adanya daya hambat pertumbuhan kedua bakteri uji, namun jamur endofit berwarna putih berserabut memiliki efek antibakteri lebih besar dari pada jamur endofit berwarna putih gading.
\end{abstract}

Kata kunci: jamur endofit, antibakteri, daun rhizophora apiculata

Indonesia memiliki kawasan pesisir pantai sangat luas yang ditumbuhi berbagai jenis tumbuhan pantai. Salah satu contoh tumbuhan pantai yaitu bakau atau mangrove. Mangrove merupakan salah satu jenis tumbuhan pantai, terutama untuk mempertahankan keseimbangan, mencegah abrasi pantai serta menjaga keindahan dari kawasan pantai. ${ }^{1}$ Mangrove terdiri atas berbagai jenis seperti semak, palma, dan 
tumbuhan paku-pakuan. Secara umum, mangrove diklasifikasikan ke dalam famili Rhizophoraceae, Sonneratiaceae, dan Ceriops. ${ }^{2}$

Aviciniaceae,

Jenis Rhizophoraceae khususnya Rhizophora apiculata tumbuh pada tanah yang berlumpur, berpasir, dan tergenang. Rhizophora apiculata merupakan salah satu jenis tumbuhan yang paling banyak pada kawasan pesisir pantai dengan ketinggian pohon yang dapat mencapai $30 \mathrm{~m}$ dengan diameter pohon mencapai $50 \mathrm{~cm}^{3}$

Jamur endofit merupakan mikroorganisme yang hidup di dalam sistem jaringan tumbuhan seperti biji, daun, bunga, ranting, batang, dan akar. Jamur endofit dapat diisolasi dari daun Rhizophora apiculata. Penelitian Kartika

tahun 2014, mengungkapkan bahwa jamur endofit yang diisolasi dari akar tumbuhan mangrove Rhizhophora apiculata kemungkinan mempunyai efek sebagai antibakteri. ${ }^{4}$

Antibiotik ialah zat yang dihasilkan oleh suatu mikroba terutama fungi, yang dapat menghambat dan membunuh mikroba jenis lainnya. Antibiotik sebagai obat yang digunakan untuk membunuh mikroba penyebab infeksi pada manusia, ditentukan harus memiliki sifat toksisitas selektif setinggi mungkin. Artinya, obat tersebut haruslah bersifat sangat toksik untuk mikroba, tetapi relatif tidak toksik terhadap penggunanya. ${ }^{5}$

Penggunaan antibiotik yang tepat dan benar seperti cara pemberian, jumlah dosis yang diberikan, waktu pemberian, serta pemilihan obat antibiotik akan memberikan efek yang baik bagi penyembuhan penderita. Bila penggunaannya tidak tepat, ditakutkan akan meningkatkan kejadian resistensi bakteri terhadap suatu antibiotik. ${ }^{6}$ Rumah sakit merupakan salah satu tempat berkembangnya bakteri yang multiresisten terhadap antibiotik, terutama bakteri Gram negatif salah satunya yaitu Psedomonas aeruginosa yang banyak ditemukan di ruang ICU. ${ }^{7}$

Psedomonas aeruginosa adalah bakteri Gram negatif yang berbentuk batang, dapat bergerak, dan bersifat aerob. Pseudomonas banyak ditemukan di tanah, air, tumbuhtumbuhan, manusia dan binatang. Psedomonas aeruginosa kadang membentuk koloni dalam tubuh manusia dan merupakan kelompok patogen yang dapat menginfeksi manusia. ${ }^{8}$

Kejadian resistensi antibiotik juga terjadi pada infeksi bakteri Gram positif seperti Staphylococcus aureus. Bakteri ini merupakan patogen utama pada manusia. Hampir semua orang pernah mengalami infeksi bakteri $S$. aureus dalam hidupnya dengan derajat keparahan yang beragam dari keracunan makanan akibat toksiknya atau infeksi kulit ringan sampai berat. ${ }^{9}$ Toksin yang dihasilkan oleh bakteri ini dapat memenyebabkan seseorang terkena diare jika terkontaminasi di makanan. ${ }^{10}$

Berdasarkan uraian di atas, peneliti tertarik untuk melakukan penelitian mengenai uji antibakteri jamur endofit yang diisolasi dari daun mangrove Rhizophora apiculata terhadap bakteri uji Pseudomonas aeruginosa dan Staphylococcus aureus yang mungkin mempunyai efek antikbakteri.

\section{METODE PENELITIAN}

Penelitian ini merupakan penelitian observasional eksperimental. Dilakukan pada bulan September 2014 sampai Januari 2015 di Laboratorium Farmakologi dan Terapi Fakultas Kedokteran Universitas Sam Ratulangi Manado. Pengambilan sampel dilakukan di kawasan pantai Tasik Ria Resort Manado.

\section{Alat dan Bahan}

Alat yang digunakan dalam penelitian ini antara lain: cawan petri, pinset, tabung reaksi, inkubator, api bunsen, kapas lidi steril, jarum ose, timbangan, sendok teh, tabung Erlenmeyer, autoclave, kompor gas, gunting. Bahan yang digunakan antara lain: daun mangrove Rhizophora apiculata, bakteri Pseudomonas aeruginosa dan Staphylococcus aureus, kapas steril, kertas saring, tisu, alkohol 70\%, plester putih, Nutrien Agar (NA), Malt Extract Agar (MEA), Müller Hinton Agar (MHA), Brain Heart Infusion (BHI), agar, akuades. 


\section{Sterilisasi Alat}

Alat-alat yang digunakan dalam penelitian ini disterilkan terlebih dahulu. Alat-alat gelas disterilisasi kering dalam oven pada suhu $170^{\circ} \mathrm{C}$ selama \pm 1 jam. Media NA, MEA, MHA, atau BHI disterilkan dalam autoclave pada suhu $121^{\circ} \mathrm{C}$ selama 15 menit (sterilisasi basah).

\section{Isolasi Jamur Endofit}

Daun mangrove jenis Rhizophora apiculata diambil dan dibersihkan menggunakan air mengalir. Pinset dan gunting direndam dalam alkohol 70\%. Daun $R$. apiculata diambil menggunakan pinset steril di rendam dalam alkohol $70 \%$, kemudian digunting empat persegi menggunakan gunting steril. Potongan tersebut selanjutnya ditanam menggunakan kawat ose ke dalam media Malt Extract Agar (MEA) dalam cawan petri, sebelumnya media ditambahkan kloramfenikol 0,2 g/L. Tutup cawan petri yang berisi daun dengan plester, kemudian simpan pada suhu kamar $\left(25^{\circ} \mathrm{C}\right)$ selama $2 \mathrm{x}$ 24 jam untuk menumbuhkan jamur. Lihat pertumbuhan jamur setelah 2x24 jam.

\section{Pemurnian Jamur Endofit}

Miselium jamur yang telah tumbuh diambil dari permukaan agar dengan menggunakan kawat ose steril dan dipindahkan ke media agar lainnya dengan maksud untuk memurnikan pertumbuhan jamur endofit. Hal ini dilakukan pada tiap jamur endofit yang secara morfologi berbeda yang tumbuh dari potongan daun tersebut. Cawan petri kemudian disimpan pada suhu ruangan selama 2 x 24 jam.

\section{Penyiapan Media Agar Miring dan Bakteri Uji}

Nutrient Agar (NA) ditimbang sebanyak 2,3 gram dan dilarutkan dalam $100 \mathrm{ml}$ akuades. Media kemudian disterilisasi dalam autoclave pada suhu 1210 C selama 15 menit. Selanjutnya media dituang dalam tabung reaksi sebanyak $7 \mathrm{ml}$ dan dibiarkan mengeras dengan kemiringan 150. Brain Heart Infusion (BHI) ditimbang sebanyak 3,7 gram kemudian dilarutkan dalam $100 \mathrm{ml}$ akuades. Media BHI disterilisasi dengan autoclave pada suhu 1210 C selama 15 menit. Media selanjutnya dituang ke tabung reaksi sebanyak $5 \mathrm{ml}$ untuk selanjutnya digunakan sebagai media suspensi bakteri. Bakteri yang dikultur pada agar miring diambil dengan kawat ose steril dan dimasukkan ke dalam media BHI. Suspensi bakteri kemudian digoreskan dengan kawat ose steril di permukaan media kombinasi. Jamur endofit yang telah tumbuh pada media MEA (Malt Extract Agar) kemudian dipotong membentuk bulat dan diletakkan pada media kombinasi MEA (Malt Extract Agar) dan MHA (Mueller Hinton Agar) yang telah digoresi bakteri uji. MHA ditimbang sebanyak 1,9 gram dan MEA ditimbang sebanyak 1,25 gram, selanjutnya dilarutkan dalam $100 \mathrm{ml}$ akuades. Media tersebut disterilisasi di autoclave dengan suhu $121^{\circ} \mathrm{C}$, kemudian tuang pada cawan petri, yang kemudian digunakan sebagai media kombinasi.

\section{Uji Kemampuan Daya Hambat Jamur Endofit dan Pengukuran Diameter Zona Hambat}

Penanaman jamur di media kombinasi dilakukan masing-masing 3 sampel jamur di 3 tempat pada 1 cawan petri dengan jarak yang simetris. Kloramfenikol sebagai kontrol positif dilarutkan sebanyak 0,2 g/L. Kertas saring yang berbentuk bulat berdiameter 0,6 cm dicelup ke dalam larutan antibiotik, kemudian diletakkan di tengah-tengah media, selanjutnya diinkubasi pada suhu kamar $\left(25^{\circ} \mathrm{C}\right)$. Zona hambat dari masing-masing sampel jamur endofit diamati setelah 1 x 24 jam. Pengukuran zona hambat dilakukan dengan menggunakan penggaris dengan cara membalik cawan petri dan mengukur diameter daerah jernih.

\section{HASIL PENELITIAN}

Jamur endofit yang berasal dari potongan daun tumbuhan mangrove Rhizophora apiculata yang ditanam di media Malt Extract Agar (MEA) diperoleh dua jenis jamur yang berbeda secara 
makroskopik. Dari hasil isolasi jamur pertama, kemudian dimurnikan kembali dan didapatkan dua jenis jamur. Secara makroskopik jamur A memiliki karakteristik yaitu jamur berwarna putih gading sedangkan karakteristik jamur B yaitu miselium berwarna putih berserabut. Hasil pemurnian dapat dilihat pada Gambar 1 dan 2.

Bakteri uji Pseudomonas aeruginosa digoreskan pada media kombinasi MEA dan MHA, kemudian ditanam 3 sampel percobaan jamur berwarna putih gading dan juga jamur berwarna putih berserabut pada cawan berbeda serta kontrol di bagian tengah. Hal yang sama dilakukan juga untuk bakteri Staphylococcus aureus.

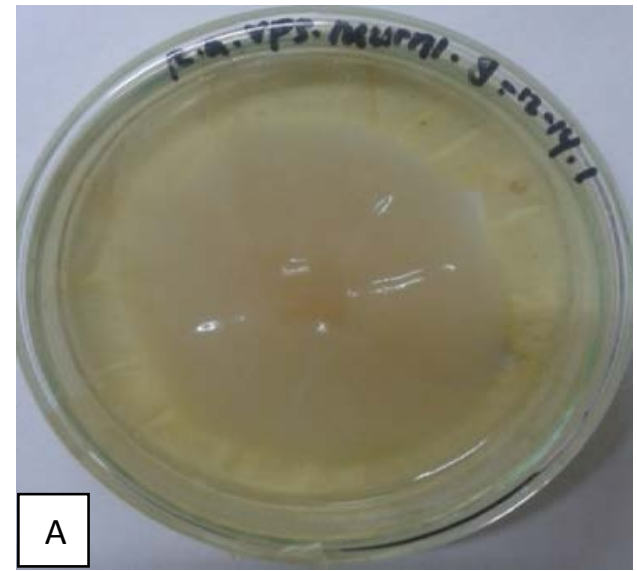

Gambar 1: Jamur endofit berwarna putih gading

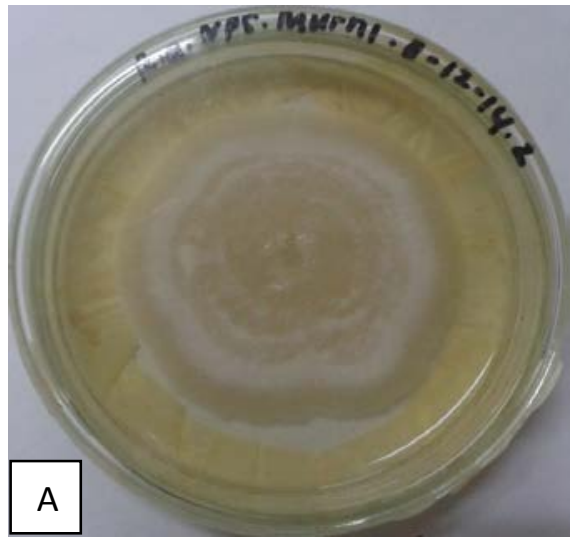

Gambar 2: Jamur endofit berwarna putih berserabut

\section{Penelitian ke-1}

Penelitian pertama dengan bakteri uji Pseudomonas aeruginosa dan 3 sampel jamur berwarna putih gading dan jamur putih berserabut masing-masing berdiameter $10 \mathrm{~mm}$ serta 1 kontrol positif di bagian tengah. Hasil pengukuran diameter dapat dilihat pada Tabel 1, sedangkan diameter zona hambat dapat dilihat pada Gambar 3.

\section{Penelitian ke-2}

Penelitian kedua dengan bakteri Staphylococcus aureus dan 3 sampel jamur berwarna putih gading dan putih berserabut masing-masing jamur berdiameter $10 \mathrm{~mm}$ serta 1 kontrol positif berada di tengah media. Hasil pengukuran diameter dapat dilihat pada Tabel 2 dan diameter zona hambat dapat dilihat pada Gambar 4.

Tabel 1: Hasil Uji Efek Antibakteri Jamur Endofit Terhadap Pertumbuhan Bakteri Uji Pseudomonas aeruginosa

\begin{tabular}{ccccc}
\hline \multirow{2}{*}{ Sampel } & \multicolumn{4}{c}{ Diameter Zona Hambat } \\
\cline { 2 - 5 } & $\begin{array}{c}\text { Jamur Putih } \\
\text { Gading }\end{array}$ & $\begin{array}{c}\text { Kontrol } \\
\text { positif }\end{array}$ & $\begin{array}{c}\text { Jamur Putih } \\
\text { Berserabut }\end{array}$ & $\begin{array}{c}\text { Kontrol } \\
\text { positif }\end{array}$ \\
\hline \multirow{2}{*}{1} & 20 & 20 & 24 & 25 \\
2 & 20 & & 24 & \\
3 & 20 & 20 & 22 & \\
Rerata & 20 & 20,3 & 25 \\
\hline
\end{tabular}



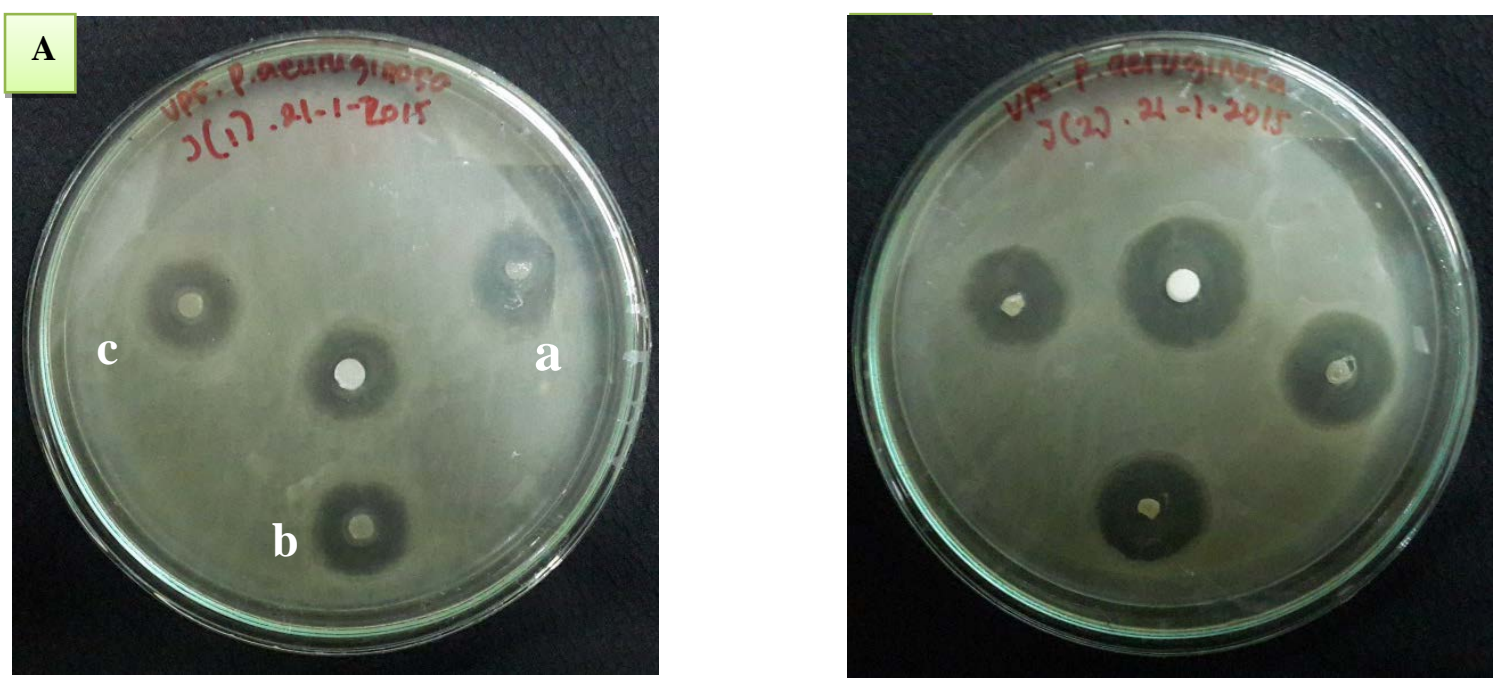

Gambar 3: A. Diameter zona hambat pada jamur endofit berwarna putih gading terhadap bakteri Pseudomonas aeruginosa, B. Diameter zona hambat pada jamur endofit berwarna putih berserabut terhadap bakteri Pseudomonas aeruginosa. (a) jamur 1, (b) jamur 2, (c) jamur 3. (garis hijau= skala $1 \mathrm{~cm}$ )

Tabel 2. Hasil Uji Antibakteri Jamur Endofit Terhadap Bakteri Uji Staphylococcus aureus

\begin{tabular}{cccc}
\hline \multirow{2}{*}{ Sampel } & \multicolumn{2}{c}{ Diameter zona hambat (mm) } & \multirow{2}{*}{$\begin{array}{c}\text { Kontrol } \\
\text { positif }\end{array}$} \\
\cline { 2 - 3 } & $\begin{array}{r}\text { Jamur Puti } \\
\text { Gading }\end{array}$ & $\begin{array}{c}\text { Jamur Putih } \\
\text { Berserabut }\end{array}$ & \\
\hline & & & \\
2. & 20 & 20 & 25 \\
3. & 20 & 24 & \\
Rerata & 21 & 24 & \\
\hline
\end{tabular}

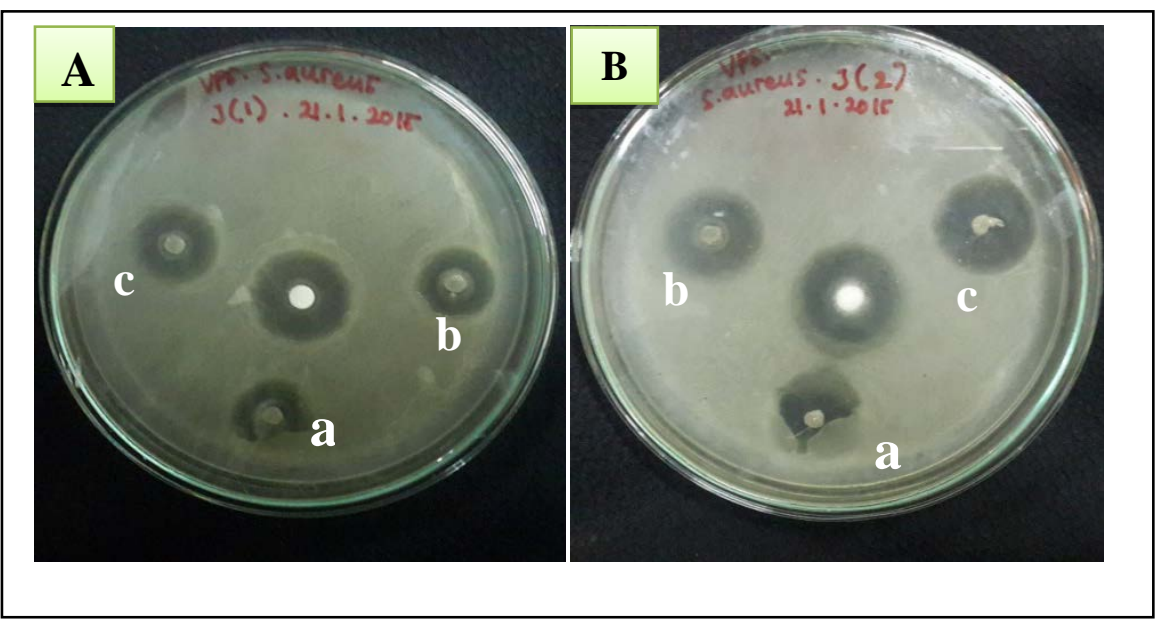

Gambar 4: A. Diameter zona hambat pada jamur endofit berwarna putih gading terhadap bakteri Staphylococcus aureus, B. Diameter zona hambat pada jamur endofit berwarna putih berserabut terhadap bakteri Staphylococcus aureus. (a) jamur 1, (b) jamur 2, (c) jamur 3. (garis hijau= skala $1 \mathrm{~cm}$ )

Dari hasil pengukuran zona hambat ketiga jamur endofit daun mangrove
Rhizophora apiculata didapatkan jamur putih gading terhadap bakteri uji 
Pseudomonas aeruginosa sebesar $20 \mathrm{~mm}$ dan untuk jamur putih berserabut terhadap bakteri uji Pseudomonas aeruginosa sebesar 23,3 mm, sedangkan untuk jamur endofit berwarna putih gading terhadap bakteri uji Staphylococcus aureus sebesar 20,3 mm dan untuk jamur endofit berwarna putih berserabut terhadap bakteri uji Staphylococcus aureus sebesar 22,6 mm. Hasil pengukuran ini memperlihatkan bahwa jamur endofit berwarna putih berserabut memberikan diameter zona yang lebih besar dibandingkan diameter zona yang ada pada jamur endofit yang berwarna putih gading.

\section{BAHASAN}

Pada penelitian ini diperoleh jamur endofit berwarna putih gading dan jamur berwarna putih berserabut. Jamur endofit berwarna putih gading dan jamur berwarna putih berserabut diisolasi dari daun tumbuhan mangrove Rhizophora apiculata. Jamur endofit yang telah diisolasi, selanjutnya dilakukan pengujian daya hambat antibakteri dengan menggunakan bakteri uji Pseudomonas aeruginosa sebagai Gram negatif dan bakteri Staphylococcus aureus sebagai Gram positif. Hasil pengujian jamur endofit daun mangrove Rhizophora apiculata terdapat daya hambat pertumbuhan bakteri. Pada pengukuran diameter zona hambat terhadap bakteri uji Pseudomonas aeruginosa didapatkan rata-rata daya hambat jamur endofit berwarna putih berserabut lebih besar dibandingkan jamur endofit berwarna putih gading. Hal yang sama juga terjadi pada bakteri uji Staphylococcus aureus yang menunjukan bahwa daya hambat jamur endofit berwarna putih berserabut lebih besar dari pada jamur endofit berwarna putih gading. Daya hambat jamur berwarna putih berserabut lebih besar, yang kemungkinan disebabkan oleh karena jamur putih berserabut mempunyai kandungan senyawa antibakteri yang lebih kuat serta konsentrasi tumbuh jamur endofit berwarna putih berserabut lebih baik dari pada jamur berwarna putih gading, sehingga mampu menghasilkan senyawa yang lebih banyak.

Jamur endofit berwarna putih berserabut mempunyai daya hambat hampir sama dengan daya hambat kontrol positif. Kontrol positif yang digunakan ialah kloramfenikol. Kloramfenikol bekerja pada spektrum luas, efektif baik terhadap Gram positif maupun Gram negatif. Kloramfenikol umumnya bersifat bakteriostatik, namun pada konsentrasi tinggi dapat bersifat bakterisid terhadap bakteri-bakteri tertentu. ${ }^{11}$ Berdasarkan mekanisme kerjanya, kloramfenikol termasuk dalam antimikroba yang menghambat sintesis protein sel mikroba yang berikatan dengan ribososm 50S. ${ }^{5}$

Pada penelitian yang dilakukan oleh Kartika dengan menggunakan jamur endofit yang diisolasi dari akar bakau Rhizophora apiculata didapatkan jamur hitam dan jamur putih. Hasil pengukuran zona hambat jamur hitam menunjukkan aktivitas penghambatan yang lebih besar dibandingkan jamur putih dengan menggunakan bakteri uji Staphylococcus aureus. ${ }^{4}$ Pada penelitian ini dengan bakteri uji yang sama namun jenis jamur yang berbeda yaitu jamur putih berserabut diperoleh diameter zona hambat yang lebih besar dibandingkan jamur hitam hasil penelitian sebelumnya. Besar zona hambat jamur hitam pada penelitian terdahulu sebesar 20,6 mm sedangkan zona hambat jamur putih berserabut dalam penelitian ini sebesar 22,6 mm.

Belum diketahui mekanisme kerja penghambatan bakteri jamur endofit berwarna putih berserabut, karena sejauh ini belum ada penelitian yang mengisolasi kandungan antibakteri yang diproduksi jamur endofit tanaman ini. Kemungkinan komponen kimia aktif yang terdapat dalam tumbuhan mangrove seperti tanin, saponin, flavonoid dan kuinon, dihasilkan oleh endofit yang senyawa bersifat sebagai antibakteri. $^{12}$

\section{SIMPULAN}

Berdasarkan hasil pengujian jamur endofit yang diisolasi dari tumbuhan 
mangrove Rhizophora apiculata terhadap bakteri Pseudomonas aeruginosa dan bakteri Staphylococcus aureus, maka disimpulkan bahwa jamur endofit yang diisolasi dari tumbuhan mangrove Rhizophora apiculata kemungkinan mempunyai efek dalam menghambat pertumbuhan bakteri Pseudomonas aeruginosa dan bakteri Staphylococcus aureus.

\section{SARAN}

Perlu dilakukan penelitian lebih lanjut kemampuan daya hambat antibakteri dengan menggunakan jamur endofit yang diisolasi dari bagian lain tumbuhan mangrove Rhizophora apiculata, perlu dilakukan penelitian lebih lanjut untuk mengetahui mekanisme kerja antibakteri pada jamur endofit yang diisolasi dari tumbuhan mangrove Rhizophora apiculata, perlu dilakukan penelitian lebih lanjut dengan menggunakan pembanding kontrol yang berbeda, dapat dikembangkan lebih lanjut untuk penelitian guna perkembangan kesehatan dibidang obat-obatan.

\section{DAFTAR PUSTAKA}

1. Suryati E, Rosmiati, Tenriulo A. Penanggulan Penyakit Bakteri Pada Udang Windu (penaeus monodon) Menggunakan Bioaktif Tanaman Mangrove Avecenia alba. Jurnal Kimia FMIPA Universitas Hasanuddin. 2007;2:19-23

2. Sulistiyowati $\mathbf{H}$. Biodiversitas mangrove di cagar alam pulau sempu. Jurnal Sainstek. 2009;8:59

3. Yessa G, Leilani I, Meriko L. Struktur Anatomi Propagul Rhizophora apiculata Blume Yang Terdapat Di Teluk Buo Kecamatan Bungus Teluk Kabung Kota Padang. Jurusan Biologi. 2012

4. Bara R, Kepel B, Bodhi W, Kartika R. Uji Daya Hambat Jamur Endofit Akar Bakau Rhizophora apiculata
Terhadap Bakteri Staphylococcus aureus dan Escherichiae coli. Bagian Kimia Fakultas Kedokteran Univeritas Sam Ratulangi. 2014;1-2.

5. Setiabudy R. Antimikroba. Dalam: Gunawan SG. Farmakologi dan Terapi. Ed 5. Jakarta: Penerbit Buku FKUI. 2007:585-9

6. Utami ER. Antibiotika, Resistensi, Dan Rasionalitas Terapi. Jurnal Sainstis. 2012;1(1):124-138

7. Adisasmito AW, Tumbelaka AR. Penggunaan Antibiotik Khususnya pada Infeksi Bakteri Penggunaan Antibiotik Khususnya pada Infeksi Bakteri Penggunaan Antibiotik Khususnya pada Infeksi Bakteri Gram Negatif di ICU Anak RSAB Harapan Kita. Jurnal Sari Pediatri. 2006;8(2):127-134

8. Brooks GF, Butel JS, Morse SA. Mikrobiologi Kedokteran (Jawetz, Melnick, \& Adelberg's Medical Microbiology). Ed 23. Jakarta: Penerbit Buku Kedokteran EGC. 2008;266-7

9. Brooks GF, Butel JS, Morse SA. Mikrobiologi Kedokteran (Jawetz, Melnick, \& Adelberg's Medical Microbiology). Ed 23. Jakarta: Penerbit Buku Kedokteran EGC. 2008;225-9

10.Wuryanti, Mulyani NS, Asy'ari M, Sarjono P.R. Uji Ekstrak Bawang Bombay sebagai Anti Bakteri Gram Positif Staphylococcus aureus dengan Metode Difusi Cakram. Jurusan Kimia FMIPA Undip. 2010;12:69-73

11.Refdanita, Maksum R, Nurgani A, Endang P. Pola Kepekaan Kuman Terhadap Antibiotika di Ruang Rawat Intensif Rumah Sakit Fatmawati Jakarta Tahun 2001 - 2002. Jurnal Makara, Kesehatan. 2004;8:41-48.

12. Yusro F. Rendemen Ekstrak Etanol dan Uji Fitokimia Tiga Jenis Tumbuhan Obat Kalimantan Barat. Jurnal Tengkawang. 2011;1:29-36. 